\title{
Profesní učitelské učení a reflexe studentského portfolia
}

\author{
HaNa LuKášOvá
}

\begin{abstract}
Abstrakt: Studie bude sledovat, jak jsme v poslednich desetiletích svèdky stále naléhavějšiho hledáni nových cest ve vyhodnocováni výsledkủ inovovaného studia ucitelství na univerzitách $v$ České republice i v zahraničí. Prí interpretaci zmèn narážime na rüzné potiže teoretické, metodologické, praktické a výzkumné.

Výraznou zmènou učitelské edukace byl prechod na pètileté magisterské studium oboru Učitelství pro 1. stupeň základních škol, který prošel náročnou diskusi se zástupci vzdèlávací politiky $v$ České republice - viz slyšení v Senátu Č́R v roce 2002. Zaméruje se na preferenci profesního učitelského rozvoje po dobu celých pèti let studia učitelství. V této stati se budeme vènovat zmèně profesního ucitelského učení pouze z jednoho zorného úhlu - jako dìkazu o výsledku zmèny na základè predchozich diskusí vzdělávací politiky. Budeme sledovat studentské portfolio jako kvalitativni nástroj $k$ hodnoceni a sebehodnoceni studentu učitelstvi pro prvni stupeň základni školy v průběhu a závèru studia. Rozebereme teoretická východiska volby portfolii jako nástroje ke sledováni profesniho učeni vědního oboru pedagogika v rámci př́pravy na učitelstvi v primárni edukaci. Reflexe studentského portfolia mũže být dokladem, který zachycuje individuálni strategie studentu prí osvojováni pedagogické teorie z primárni pedagogiky a hodnoceni výsledkù reflektované pedagogické praxe. Pedagogická praxe prostupuje spolu s pedagogickou teorii od prvního ročniku pètiletého studia Učitelstvi pro 1. stupeň základni školy v novém modelu učitelské př́pravy ve Zlinè na Fakultě humanitnich studii Univerzity Tomášse Bati. V tomto roce jsou dispozici první výsledky reflexe novè zvolené cesty učitelské př́pravy. Vyplývaji z nich i zajimavé podnèty pro vzdèlávací politiku ve vztahu k učitelské př́pravě v České republice do budoucna.
\end{abstract}

Klićová slova: profesni učitelské učeni, učitelská príprava, reflektivni model, výzkum učitelského vzdèláváni, hodnoceni profesního učení, doporučeni pro vzdèlávaci politiku

\section{ÚvOD}

$\mathrm{V}$ posledních desetiletích jsme svědky stále naléhavějšího hledání nových cest $\mathrm{v}$ oblasti vyhodnocování výsledků inovovaného studia učitelství na univerzitách v České republice i v zahraničí. Při interpretaci změn narážíme na různé potíže teoretické, metodologické, praktické i výzkumné, jak na to upozorňuje Štech (2014) i Spilková (2019a). Autoři poukazují na to, že je nutné, abychom změny jasně a kontextuálně vymezili a výzkumně reflektovali. 
Výraznou změnou učitelské edukace byl přechod na pětileté magisterské studium oboru Učitelství pro 1. stupeň základních škol, který proběhl v posledních desetiletích. Hlavní charakteristikou změn je, že studium není strukturované na bakalářský (tř́letý) a magisterský (dvouletý) stupeň a zaměřuje se na preferenci profesního učitelského učení a sebe-rozvoje po dobu celých pěti let. Devět pedagogických fakult v České republice popsalo své individuální strategie změny, která se od přijetí společného konsenzu realizovala do roku 2010 (viz Spilková \& Hejlová, 2010; Spilková, 2019a). V publikaci Spilkové a Hejlové lze najít i jiný obraz uchopení těchto změn, které se odvíjejí od přijetí Boloňské deklarace v Evropě, v podmínkách sousedního Slovenska. Zde byla zvolena zcela odlišná strategie řešení, $s$ níž můžeme české postupy porovnávat.

$\mathrm{V}$ této stati se budeme věnovat změně profesního učení pouze $\mathrm{z}$ jednoho zorného úhlu. Budeme sledovat studentské profesní učení v reflexi studentského portfolia jako jednoho z možných kvalitativních nástrojů $\mathrm{k}$ hodnocení a sebehodnocení studentů učitelství pro 1 . stupeň ZŠ v průběhu a závěru studia. Rozebereme teoretická východiska volby portfolií jako nástroje ke sledování profesního učení u studentů učitelství. Budeme si klást otázku, jakou roli může v procesu i ve výsledcích sehrávat vědní obor pedagogika, který je součástí př́pravy na učitelství v primární edukaci v aplikované podobě jako primární pedagogika.

Podrobně rozebereme možnosti individuálního profesního učení, které se může projevit ve studentském portfoliu. Může být dokladem, který zachycuje individuální strategie při osvojování si pedagogické teorie z primární pedagogiky a při hodnocení výsledků reflektované pedagogické praxe, která se prolíná s pedagogickou teorií od prvního ročníku pětiletého studia tohoto oboru. Odpovědi na otázky budou získávány i výzkumnou sondou a budou použity pro formulaci podnětů pro vzdělávací politiku do budoucna.

\section{TEORETICKÁ VÝCHODISKA \\ PRO ŘEŠENÍ PROBLÉMU \\ PROFESNÍHO UČITELSKÉHO UČENÍ}

\section{A STUDENTSKÉHO PORTFOLIA}

\section{$1.1 \mathrm{O}$ jaká východiska se opírá pojetí profesního učitelského učení v primární pedagogice?}

Model reflektivního pojetí učitelského vzdělávání v celostním holistickém modelu učitelské přípravy začal být vyvíjen týmem spolupracovníků ve Zlíně od roku 2014. Tehdy bylo možné experimentálně zavést změny do učitelské př́ípravy ve studijním programu a oboru Učitelství 1. stupně základní školy v nové akreditaci. Navazuje na předchozí výzkumy (viz podrobně Lukášová \& Ries, 2010; Lukášová-Kantorková, 2003; Lukášová, 2006, 2011, 2015; Lukášová, Majerčíková \& Svatoš; 2014).

Výchozím záměrem změn byla snaha propojit teoretickou a praktickou složku profesní učitelské přípravy pro primární edukaci. Nově pojatá učitelská příprava se 
zaměřila na to, aby byl student učitelství teoreticky připraven vědomě reflektovat svoji cestu k učitelské profesi a propojil ji s kvalitami profesní sebereflexe od začátku studia. Svůj vstup do pedagogických situací výuky a školy se student postupně učil reflektovat na základě osvojené pedagogické teorie. Byly aplikovány zkušenosti z mezinárodního úsilí o rekonstrukci učitelského vzdělávání, které probíhalo $\mathrm{v}$ širokém měřítku se změnou paradigmatu učitelského vzdělávání ve světě (Eliot, 1993) a v rámci Evropy př́i spolupráci $s$ ATEE (Associacion for Teacher Education in Europe), kde byly prezentovány výsledky výzkumu změn učitelské prŕpravy $\mathrm{v}$ rámci seminárư pracovní skupiny $\mathrm{RDC}$ 19 pro učitelské vzdělávání (Research and Development Center ATTE for Teacher Education) ve spolupráci s desítkou dalších univerzit v Evropě.

Klíčovou charakteristikou změny učitelské přípravy byl reflektivní model výuky, který už byl tehdy v Evropě zkoumán. V devadesátých letech minulého století jsme mohli sledovat obdobné snahy v zahraničí, o jejichž výsledcích informuje Korthagen se spolupracovníky (2011). $\mathrm{Na}$ Slovensku se uvedeným otázkám změn $\mathrm{v}$ učitelské př́pravě $\mathrm{v}$ primárním vzdělávání věnovali kolegové z Banské Bystrice (Kasáčová, 2005; Doušková \& Porubský, 2011; Kosová \& Porubský, 2011; Kosová, 2012, 2013).

Také v Česku byla problému inovace učitelského vzdělávání v novém paradigmatu věnována nemalá pozornost (Spilková, 2004, 2007, 2019a; Švec, 2005, 2016; Lazarová et al., 2006; Kratochvílová \&
Horká, 2007; Vašutová et al., 2008; Nelešovská et al., 2009; Spilková \& Hejlová, 2010; Spilková \& Tomková, 2010; Starý et al., 2012; Švec et al., 2016; Tomková, 2018). Inovace reflektovaly i změny kurikula a z toho vyplývajících požadavků na primární vzdělávání $\mathrm{v}$ základních školách a řešily evidenci procesů a výsledků profesního učitelského učení.

Reflektivní model učitelského vzdělávání vede studenty od deklarativních profesních znalostí (vědět co) přes procesuální znalosti (vědět jak) až ke kontextuálním profesním znalostem (vědět proč), které by studenti měli prokázat ve svých kompetencích $\mathrm{v}$ průběhu a na konci studia. Inspiraci jsme získali od zahraničních autorů Atkinsona a Glaxtona (2001, s. 7).

Aby model mohl fungovat, bylo potřebné přestavět obsah studia $\mathrm{v}$ jednotlivých studijních předmětech a propojit učební úlohy z teorie a praxe primární pedagogiky, do nichž jsou postupně zapojovány rozhodovací procesy studentů učitelství. $\mathrm{Na}$ základě desetiletí sledování procesů rozvoje studentů učitelství k profesi bylo možné zformulovat identifikátory kvality profesního seberozvoje učitele (Lukášová, 2009a, s. 59), na které se reflektivní model učitelské přípravy zaměřuje.

Mezi základními otázkami realizace reflektivního modelu výuky bylo, jak uspořádat profesní didaktické znalosti obsahu učitelského vzdělávání $\mathrm{v}$ jednooborovém studijním oboru, který v sobě zahrnuje učivo $\mathrm{z}$ devatenácti oblastí vědy, kultury, filozofie a umění. Při každé další akreditaci studijního oboru je potřebné 
znovu hledat konsenzus v proporcích mezi studijními předměty na základě profilu absolventa. $\mathrm{Na}$ základě celostní filozofie studia jsou formulovány priority, které rozloží kredity studia do jednotlivých jeho dílčích složek. To byl nový limitující faktor pro rozhodování o reflektivním modelu studia (viz Lukášová, 2009b).

Dalším limitujícím faktorem se ukázaly být krizové jevy v oblasti financování vysokých škol. Snížila se možnost financování průběžných a souvislých pedagogických praxí studentů, které jsou pro realizaci reflektivního modelu učitelského vzdělávání nezbytné. Podařilo se však uchovat propojení pedagogické teorie a praxe i v nových podmínkách a získat granty pro financování učitelů-mentorů v základních školách.

Krizové jevy učitelské přípravy souvisejí s celkovou krizí společnosti vědění (viz Liessmann, 2008), v níž se vytrácí vnímání celosti člověka, která by mohla být vzděláváním rozvíjena. Tato okolnost se bytostně týká učitelského vzdělávání, které je třeba reflektovat $\mathrm{z}$ hlediska pedagogické kultury obratu (viz Spilková \& Vašutová, 2008; Helus, 2008, 2010; Lukášová, 2011, 2015; Spilková, 2019a), jež naznačuje, jak pomáhat studentům učitelství při vypořádávání se s krizovými jevy v současném a budoucím vzdělávání.

Důraz při hledání řešení a východiska krize do budoucna je kladen na kvality profesního seberozvoje studenta učitelství v celostním pojetí, které doprovází proces osvojování didaktických znalostí učiva $\mathrm{v}$ široké škále studijních předmětů (viz Lukášová in Janík, Maňák \& Knecht, 2009, s. 57-71).
Zahraniční autoři si položili zajímavou otázku: „Měli by všichni učitelé být reflektivními praktiky?" (Korthagen et al., 2011, s. 79). Jejich odpověd' je jednoznačná a také my se s ní identifikujeme po 30 letech praktikování reflektivního modelu učitelské př́pravy a jeho pedagogického výzkumu: „Reflexe je generickou profesní dispozicí."

Korthagen dále cituje zkušenost LaBoskeye (in Korthagen et al., 2011, s. 79): „Všichni žáci si zaslouží učitele, kteří jsou ochotni i schopni svědomitě, zásadově a uvážlivě konstruovat a prověřovat svou praxi.“

Základním pilî̌rem profesní učitelské pŕípravy a oporou pro spolupráci akademiků, učitelů praxe i studentů může být společné sdílení filozofie edukační kultury obratu, která se opírá o konstruktivistické pojetí kurikula učitelské přípravy. Aplikaci reflektivního př́istupu ke kvalitám života učitelství pro př́pravu studentů jsou věnovány texty z pedeutologie. (Lukášová, 2015).

Najdeme $\mathrm{v}$ nich i fenomenologické východisko ke zkoumání problému studentského profesního učení, které koresponduje $s$ výsledky nejnovějš́ího pedagogického výzkumu v zahraničí. Např́iklad Yough, Gilmetdinova a Finneyová (2020) zvolili fenomenologický př́stup a výsledky jejich výzkumu naznačují, že podstatou profesního učení je získaná potřeba pocitu naplnění (fulfillment). Pocitovaná subjektivní odpovědnost, kterou také získává student učitelství v reflektovaném modelu učitelské př́ípravy, souvisí se sebeurčením studentů, je ovlivňována prostředím stu- 
dia a má vliv na emoce studentů učitelství (viz také Pečivová, 2019, 2021).

Tak vznikla i navazující otázka, jak by se dal zachytit proces kvalitativní reflexe profesního učitelského učení. Odpovědi na tuto otázku se budeme věnovat $\mathrm{v}$ další části textu.

\section{$1.2 \mathrm{O}$ jaká teoretická východiska a kontexty se opírá používání studentského portfolia $v$ učitel- ském vzdělávání?}

Ukázalo se, že je potřebné pokusit se zjistit, zda studentské portfolio je odpovídajícím nástrojem pro zachycení kvality procesů profesního učení.

Jednu z možností, jak teoreticky chápat studentské portfolio, vymezila Vašutová (2002, s. 234) následovně: „Studentské portfolio lze označit za nadčasový produkt průběžného aktivního studia. Jeho podstata spočívá $v$ inventarizaci veškerých písemností, dokumentů a intelektuálních produktů, které student vytváŕí nebo získá jako cenné materiály $\mathrm{v}$ průběhu části nebo celého studia."

Vidíme, že pojem profesní učitelské portfolio je vymezen v odborné literatuře jako soubor materiálů, dokumentů a artefaktů (výtvorů), jejichž podoba se odvijjí od teoretických východisek procesů tvorby a využití. Jak se dále můžeme dočíst, „jde o individualizovaný portrét učitele-profesionála reflektujícího svoji filozofii a praxi“ (Píšová, 2007, s. 41). Obdobně můžeme uvažovat i o studentském portfoliu v období profesní př́pravy jako o individualizovaném portrétu profesní cesty studenta učitelství k profesi, doklad o jeho profesním učení.

Podoba profesního učitelského portfolia se také stala předmětem pedagogického výzkumu v zahraničí (viz Vavrus \& Collins, 1991; Kennet, 1996; Lyons et al., 1998; Heller et al., 1998; Mabra, 1999; Klenowski, 2004) a má už svou historii i v Česku a na Slovensku (Spilková, 2004, 2007; Svatoš, 2006; Svatoš \& Holý, 2007; Píšová, 2007; Doušková, 2007; Havel \& Filová, 2007; Kratochvílová, 2007; Kratochvílová \& Horká, 2007; Prokešová \& Stuchlíková, 2008; Spilková \& Tomková, 2010; Doušková \& Porubský, 2011; Píšová, Duschinská et al., 2011; Tomková, 2018).

$\mathrm{V}$ zahraničí byla portfoliu předpovězena už perspektivní budoucnost, protože umožňuje používat holistické přístupy v hodnocení výsledků učení (Mabra, 1999). Heller a jeho spolupracovníci ocenili skutečnost, že portfolio umožňuje překonat různé typy redukcionismu v hodnocení procesů učení, což je pro profesní hodnocení učitelské připravenosti k výkonu profese velmi důležité. (Heller et al., 1998).

Spilková a Tomková uvádějí (2010, s. 160), když shrnují odpověd' na otázku, co může profesní portfolio pro certifikaci obsahovat, že lze sledovat následující podklady: ukázky příprav, zejména týdenní plány, které demonstrují dovednost plánovat integrované tematické celky; doklady o spolupráci a komunikaci s rodinou a komunitou, rozmanité písemné materiály (například školní zpravodaje, třídní časopis, informační letáky, osobní pozvánky, 
zprávy od rodičů, zpětné vazby od rodičů, záznamy a dokumentace mimoškolních akcí pro rodiče a děti); záznamy o pozorování dětí (např́íklad pozorovací archy, sebehodnoticí archy, epizodické záznamy, záznamy rozhovorů s dítětem); individuální vzdělávací plány dětí, videozáznamy vyučovacích hodin, fotografie nebo načrtnuté plánky prostorového uspořádání učebny do center aktivit ve své třídě; autentické práce, např́íklad písemné produkty, vyhodnocené práce žáků, sebehodnocení žáků, projekty, mapy, experimenty; plán dalš́ho vzdělávání a profesního vývoje a důkazy o jeho plnění; postřehy a hodnocení ze strany kolegů; hodnocení, ocenění a doporučení ředitele školy, rodičů i dalších rozmanitých subjektů vzdělávání, potvrzení o úspěšném absolvování kurzů dalš́ího vzdělávání.

Zde vidíme ukázku toho, jak může vznikat individualizovaný portrét profesního rozvoje a seberozvoje $\mathrm{v}$ profesním učení, který strukturované portfolio může poskytnout. Individualizovaný portrét studentova profesního osvojování učitelství může být i v prezentačním portfoliu (ukázkovém), o němž budeme v této studii hovořit $\mathrm{v}$ rámci vlastního pedagogického výzkumu.

Pro rozhodování o účelu, obsahu, organizaci a formě portfolia je potřebné sdílení společného paradigmatu učitelské př́ípravy.

Význam portfolia v reflektivním a konstruktivistickém modelu učitelského vzdělávání pro primární edukaci vyhodnotila i Spilková (2007, 2019b) a Tomková (2018). V Praze na Pedagogické fakultě UK byla vytvořena možnost obhajovat portfolio u státní závěrečné zkoušky jako alternativa $\mathrm{k}$ tradičnímu postupu. Na základě principu individuální tvorby a volitelnosti pro studenty byl postupně formulován rámcový obsah profesního učitelského portfolia ke státní závěrečné zkoušce $\mathrm{z}$ pedagogiky následovně: vybrané práce (pedagogicko-psychologické disciplíny, oborové didaktiky) s komentářem, proč byly vybrány, v čem ovlivnily profesní vývoj (seminární a ročníkové práce, projekt, tvorba pomůcky či didaktického materiálu); doklady pedagogické praxe (reflektivní deník, př́ípravy na hodiny, foto- a videodokumentace, reflexe od spolužáků a fakultních učitelů); autografický popis profesního vývoje eseje, př́iběhy, myšlenkové mapy, profesní životopis - Moje cesta k učitelství, Moje pojetí výuky; recenze a anotace odborné literatury. Pro obhajobu portfolia bylo třeba stanovit dostatečný časový předstih před konáním závěrečné státní zkoušky z pedagogiky, který by umožnil čelenům státnicové komise, aby se v předstihu seznámili s obsahem portfolia.

Také na Pedagogické fakultně Jihočeské univerzity v Českých Budějovicích byly vytvořeny dvě alternativy, jak zapojit aplikaci profesního portfolia studentů učitelství do státních závěrečných zkoušek. První alternativa je zamýšlena jako propojení s tradiční organizací zkoušky, kdy student má k dispozici své prezentační portfolio. Druhá alternativa počítá s účastí odborníků, kteří předem prostudovali a posoudili profesní studentské portfolio, jež je obsahem zkoušky. $\mathrm{K}$ tomuto účelu byly stanoveny dva okruhy kritérií, podle nichž se 
může finální hodnocení řídit (Prokešová \& Stuchlíková, 2008, s. 130): Návrh kritérií pro hodnocení obsahové stránky prezenčního portfolia - porozumění zvolenému problému (posouzení míry porozumění, zaujetí problémem, dlouhodobost jeho řešení); reflexe průběhu utváření portfolia (odůvodnění výběru a způsobu práce $s$ materiály, produkty apod.); argumenty pro zvolený př́stup $\mathrm{k}$ otázkám (problémům), které autor pokládá v tématu za nosné - invence, originalita apod.; využitelnost zjištěných skutečností a získaných zkušeností v další profesní činnosti, popř́ípadě pokus o zhodnocení absolvované př́pravy (představy o dalším rozvoji). Návrh kritérií pro hodnocení způsobu prezentace portfolia před komisí pro státní závěrečné zkoušky - srozumitelná formulace myšlenek, sdělnost; přesvědčivá argumentace; zajímavý způsob prezentace vybraných materiálů; pohotová a věcně správná reakce na dotazy členů komise; kultivovaný a působivý projev (volba takových prostředků komunikace, které odpovídají dané situaci). Autorky studie informovaly o tom, že při formulaci výsledných kritérií braly v úvahu i výsledky výzkumných sond mezi studenty.

Na základě uvedených požadavkủ bylo potřebné hledat i nové podoby portfolií, jež jsou schopny zachytit finální podobu kontextuálních znalostí studentů učitelství a reflexi cest profesního učitelského učení během studia, což bylo realizováno v letech 2014-2020 ve Zlíně. Realizací celostního modelu reflektivního osvojování profesního učení jsou sledovány u studentů učitelství následující cíle: tvorba pod- mínek k smysluplnému profesnímu učení, tvorba vlastního pedagogického díla studentů a aplikace výzkumných kompetencí. Položili jsme si otázky: Jak student tvoři portfolio? Jak v něm dokumentuje připravu, realizaci a evaluaci $k$ reflektované pedagogické praxi? Pokusíme se odpovědět na otázky, jak probíhá profesní učení studentů učitelství v aplikovaném modelu nově akreditovaném v roce 2019 ve Zlíně na Fakultě humanitních studií. Na modelu spolupracují vysokoškolští učitelé z Ústavu školní pedagogiky UTB i učitelé základních škol v regionu.

Studenti oboru Učitelství pro 1. stupeň ZŠ si zakládají své pracovní profesní portfolio od prvního semestru studia a předkládají ho u dílčích zkoušek z primární pedagogiky. Dále v textu jsou charakterizovány jednotlivé předměty primární pedagogiky i se zadanými úkoly, jež studenti řeší v průběhu 10 semestrů. $\mathrm{V}$ učitelství pro 1 . stupeň základní školy je primární pedagogika rozložena jako základní pilî́ do všech deseti semestrů magisterského studia. Jde o zastoupení základních vybraných pedagogických věd $\mathrm{v}$ aplikované podobě ve studijních předmětech primární pedagogika 1-10. Jsou vytvářeny podmínky pro osvojování obsahu pedagogických věd tak, aby student mohl zvolit seminární práce $s$ individuálním zaměřením $\mathrm{k}$ vybraným tématům do větší hloubky.

První semestr - Pedagogika primárního vzdělávání $1 \mathrm{~s}$ praxí se opírá v profesionalizaci o témata obecné pedagogiky. Nezačínáme jen obecnými pojmy výchova a vzdělávání, ale reflexí osobní 
zkušenosti s výchovou $\mathrm{v}$ rodině a ve škole ve vlastním životním příběhu. Reflexe zvláštností individuálních koncepcí výchovy ukazuje hned na začátku na některá rizika individuálních zkušeností studentů. Porovnání prekoncepcí výchovy vede $\mathrm{k}$ motivaci poznávat podstatu výchovy jako lidského fenoménu. Pochopení mnoha-parametrických rozměrů výchovy může vyústit $\mathrm{v}$ motivaci hledat takové př́istupy $\mathrm{k}$ výchově a vzdělávání, které jsou schopny podporovat hodnoty lidskosti jedince. První zkušenosti studenta na cestě od empirického pozorování $\mathrm{k}$ zobecnění mohou být velmi osobní. Novou zkušeností je písemné zpracovávání odborných textů z pedagogiky. Student je veden k vyhledávání časopisecké a monografické literatury, která řeší výchovné a vzdělávací problémy. Zpracovává problém, který si sám volí $\mathrm{z}$ okruhů učiva obecné pedagogiky, ve formě konspektu. Učí se odlišit vlastní vidění pedagogických problémů od postojů autora, který problém zpracovává v teorii na různé úrovni zobecnění, učí se formulovat hodnocení teoretických poznatků z hlediska přínosu pro nové, praktické vidění pedagogických jevů. V prvním semestru zajištujeme rozvoj pedagogického myšlení v pohybu od reflexe prožívání individuálních zkušeností z vlastní praxe výchovy a vzdělávání $\mathrm{k}$ teoretickému osvojení základních pojmů pedagogiky a k prožitku smyslu konfrontace individuální zkušenosti s jinou zkušeností, která je uložena v pedagogické literatuře a školních vzdělávacích programech, jež jsou sledovány na pedagogických praxích regionálních škol.

\section{Druhý semestr - Pedagogika pri-} márního vzdělávání $2 \mathrm{~s}$ praxí obohacuje profesionalizaci o aplikovaná témata $\mathrm{z}$ dalši vědní disciplíny - teorie výchovy. Tento semestr je zaměřen na oblast lidských hodnot a na obsah a cíle výchovy, které $s$ nimi souvisejí. Na jedné straně studenti sledují různé skupiny hodnot v teorii. $\mathrm{Na}$ druhé straně se snaží posoudit, jakou podobu měly hodnoty lidství jako prav$\mathrm{da}$, láska, dobro a krása $\mathrm{v}$ jejich výchově a vzdělávání ve vlastním dětství a dospívání. Studenti písemně vyhodnocují svou vlastní konfrontaci s lidskými hodnotami a ctnostmi, které promýšlejí z pedagogické teorie. Uvědomují si, které dimenze lidskosti jsou u nich vyvinuty a v jaké kvalitě. Jsou motivováni $\mathrm{k}$ sebepoznávání z tohoto hlediska profesních učitelských ctností. Studenti jsou vedeni $\mathrm{k}$ prožitku odpovědnosti za transformaci hodnot lidskosti do praxe výuky žáků v primární edukaci. Tento úkol vyústí do prrípravy a realizace prvních pozorování výuky a prvních pokusů vyučovat. Studenti navštíví svou školní třídu a pozorují průběh vyučovacích hodin, prostředky a organizaci řešení výchovných problémů dětí a klima školní třídy. Následně realizují své vlastní první pokusy vyučovat. $\mathrm{Na}$ pedagogické praxi studenti sledují školní připravenost a zralost žáků při zápisu do školy a pomáhají s organizací.

Třetí semestr - Pedagogika primárního vzdělávání $3 \mathrm{~s}$ praxí se opírá o vědní základ obecné didaktiky. V rámci pedagogických praxí sledují studenti vyučovací hodiny $\mathrm{z}$ hlediska vybraných didaktických jevů (cíle, obsah, metody, formy, 
prostředky, kontrola učebních činností a práce s chybou žáka, způsob hodnocení a sebehodnocení výsledků výuky apod.), které jsou také předmětem přednášek a seminářů. Vedle prvků procesu výuky sledují studenti po celou dobu pedagogické praxe jednoho vybraného žáka. Písemně posuzují, jak žák zvládá požadavky výuky vzhledem ke svým zvláštnostem. Studenti pozorují, jak individuální zvláštnosti dětí vstupují do celého procesu výuky, jak rozdílné jsou výsledky učebních činností u jednotlivých žáků. Student dostává pravidelnou zpětnou vazbu $\mathrm{k}$ protokolům $\mathrm{z}$ pedagogické praxe, jíž je veden $\mathrm{k}$ tomu, aby stále důsledněji použival pojmy didaktické teorie $\mathrm{v}$ popisu pozorovaných jevů ve výukové praxi. Semestr je zakončen projektem jedné vyučovací hodiny, který společně tvoří 3-4 studenti ve skupině. Výsledné pokusy vyučovat po absolvování obecně-didaktického základu navazují na hospitace ve výuce. Studenti se domlouvají s vyučujícím, zpracují písemnou přípravu a tu realizují ve vyučovacích hodinách. Semestr končí reflexí pokroku v plánování a realizaci výuky.

Čtvrtý semestr - Pedagogika primárního vzdělávání $4 \mathrm{~s}$ praxí se opírá o vědní základy pedagogické diagnostiky. Pedagogická diagnostika je jednou z dalších klíčových disciplín pro učitele primární školy. Je to teorie a praxe zjištování, pozorování, klasifikování, posuzování, charakterizování, hodnocení úrovně rozvoje dětí nebo celé třídy. Praktické pedagogicko-diagnostické činnosti by měly být zaměřeny např́íklad na problémy školní zralosti, na zvláštnosti, které vyžadují in- dividuální přístup k dítěti, na diagnostiku př́ičin školního neúspěchu žáka, na výchovné obtíže, ale též na sledování schopností a rozvoj nadání a talentu ve výuce. Úkoly pedagogické praxe na teorii navazují a jsou soustředěny na shromažd'ování podkladů pro napsání žákovské pedagogické kazuistiky jednoho z pozorovaných žáků.

Pátý semestr - Pedagogika primárního vzdělávání $5 \mathrm{~s}$ praxí je zaměřena na osvojení témat $\mathrm{z}$ komparativní pedagogiky v aplikované podobě pro učitele v primární edukaci. $\mathrm{V}$ této disciplíně je prováděno porovnávání vzdělávacích př́istupů a systémů ve světě. Důraz je kladen na nové tendence $\mathrm{v}$ oblasti vzdělávání malých dětí. Předmětem zájmu jsou reformní trendy ve školství a v alternativním pedagogickém myšlení, jež vychází z různých možností vzdělávání, z globální výchovy nebo integrované tematické výuky a projektové výuky. Kurz se zaměruje také na hlubší pronikání do čtyř základních pilírư vzdělávání formulovaných $\mathrm{v}$ materiálech UNESCO a OECD, v Bílé knize, dnes ve Strategii 30+ apod. Výchova k porozumění evropské dimenzi ve vzdělávání a $\mathrm{k}$ dětské identitě $\mathrm{v}$ uvedeném kontextu může být předmětem vědecko-výzkumné činnosti učitelů i studentů komparativními metodami. Vše se realizuje i z hlediska historického kontextu a ve vztahu $\mathrm{k}$ dějinám pedagogiky.

\section{Šestý semestr - Pedagogika primár-} ního vzdělávání $\mathbf{6} \mathbf{s}$ praxí se opírá o otázky pedeutologie jako vědní disciplíny. Soustředuje se na pojetí fází profesního vývoje a také na reflexi aspektů učitelské- 
ho sebepojetí. Studenti zpracovávají seminární práci, v níž sledují profesní rozvoj jednoho vybraného učitele $\mathrm{z}$ praxe a zachycují aspekty jeho profesního a životního př́iběhu. Sebepojetí se učí reflektovat i na vlastním seberozvoji během studia. Seminární práce se zaměřují na kvality učitelského seberozvoje v oblasti tělesné, duševní a duchovní.

Sedmý semestr - Pedagogika primárního vzdělávání $7 \mathrm{~s}$ praxí. $V$ rámci tohoto semináre student konzultuje své vlastní záměry pedagogické volby a tvorby při zpracovávání pedagogického problému, který si volí na základě studia teorie nebo absolvované pedagogické praxe. Spolu s vyučujícím pedagogiky formuluje student pedagogický problém, který koresponduje s okruhy ke státní závěrečné zkoušce $z$ pedagogiky a psychologie. Student navrhuje řešení na základě prostudované teorie. Sestavuje pojmovou mapu řešení a seznam studované literatury. Navrhuje sledování problému pomocí vybraných diagnostických metod $\mathrm{v}$ rámci návrhu řešení pro závěrečnou pedagogickou praxi.

Osmý semestr - Pedagogika primárního vzdělávání $8 s$ praxí. Výuka se zaměřuje na prrípravu souvislé šestitýdenní závěrečné pedagogické praxe, $\mathrm{v}$ jejím rámci může proběhnout i projektová praxe a řešení pedagogického problému a jeho psychologických aspektů. Student je dále veden $\mathrm{k}$ písemnému zpracování teoretických východisek a definitivních diagnostických postupů pro řešení pedagogického problému. Písemně zpracovává také teoretický pedagogický a psychologický aspekt pedagogického problému do hloubky a hledá zajímavé postupy řešení pro pedagogickou praxi. Obojí připravuje jako písemnou zprávu o návrhu na realizaci $\mathrm{k}$ řešení pedagogického problému. Formuluje dopředu očekávané výsledky řešení pedagogického problému pro závěrečnou šestitýdenní pedagogickou praxi.

Devátý semestr - Pedagogika primárního vzdělávání $9 \mathrm{~s}$ praxí završuje předchozí kroky. Všechny dílčí části portfolia (řešení pedagogického problému a jeho psychologického aspektu) odevzdává student $\mathrm{k}$ zápočtu a jsou součástí písemného podkladu pro státní závěrečnou zkoušku z pedagogiky a psychologie. V tomto období student získává zpětnou vazbu na písemné podklady a může konzultovat problémy, s nimiž se při přehledném zpracování setkává.

$\mathrm{V}$ závěrečném, desátém semestru je předmětem diskuse zpětná vazba učitele na řešení pedagogického problému studenta. Student je veden k obhajobě svých řešení a $\mathrm{k}$ překonávání metodologických obtíží při didaktickém zpracovávání pedagogického problému v praxi. Obsahové a formální dopracování písemných materiálů ke státní závěrečné zkoušce - závěrečné ukázkové strukturované portfolio - je obsahem blokových seminárních konzultací i předmětem zápočtu. Jde o celkovou evaluaci pedagogické a didaktické složky studia. Studenti se navzájem seznamují s hodnocením učitelů z praxe a konfrontují je s vlastním sebehodnocením.

Podrobná informace $\mathrm{k}$ propojení pedagogické složky studia na další složky studijního programu a oboru je 
k dispozici na adrese: https:/fhs.utb.cz/ studium/prijimaci-rizeni/prehled-oboru-nafhs/studijni-program-ucitelstvi-pro-zakladniskoly-studijni-obor-ucitelstvi-pro-1-stupenzakladni-skoly-prezencni-forma/

\section{VÝZKUMNÉ ŠETŘENÍ}

Hlavním záměrem výzkumného šetření je popsat zkušenosti studentů $s$ využitím portfolia $\mathrm{v}$ průběhu a závěru studia oboru učitelství pro 1 . stupeň základní školy.

\subsection{Cíle empirického výzkumu}

- Zjistit, jaké produkty studentů ze studia reprezentují jejich profesní učení v individuálním portfoliu.

- Posoudit, jak studentské portfolio dokumentuje kvalitativní kroky na osvojování učitelské profese.

- Vybrat důkazy ze studentských reflexí portfolia pro rozhodování o budoucích požadavcích na učitelskou profesi.

- Navrhnout do budoucna opatření k učebním činnostem se studentským portfoliem př̀i osvojování učitelské profese.

\subsection{Otázky výzkumu}

- Jaké jsou typy produktů studia primární pedagogiky, které studenti vkládají do individuálních portfolií?

- Co ve studentském portfoliu dokumentuje reflexi teoretických základů studia učitelství?

- Jak studenti dokumentují reflexi náslechové pedagogické praxe?
- Jaké reflexe studenti formulují vzhledem k jejich vlastním pokusům vyučovat?

- Jaké názory na osvojování učitelské profese lze u studentů identifikovat v portfoliu z hlediska propojení teoretické a praktické složky studia?

\subsection{Výzkumný postup a metody}

Studenti tř́ ročníků studia dali svá portfolia $\mathrm{k}$ dispozici pro obsahovou analýzu individuálních reflexí cesty $\mathrm{v}$ rámci profesní př́ípravy na učitelství v primární edukaci.

Obsahová analýza dokumentu se řídila v postupu základními doporučeními Gavory (2000, s. 118-119). Jde o nekvantitativní analýzu textu. (1) Bylo provedeno vymezení základního souboru textů studentského portfolia studentů oboru Učitelství pro 1. stupeň základní školy. Jde o soubory textů, které si studenti 1.-5. ročníků vkládají do studentských portfolií. Stanovení výběrového souboru bylo nutné, protože jde o obsáhlé složky, které studenti kompletují jako souborné portfolio. Byl proveden výběr jednoho z nich na základě kritéria důkladnosti a úplnosti vložených textu. (2) Jako významová jednotka byl stanoven výběr témat pedagogické teorie a reflektované pedagogické praxe, které odpovídají indikátorům $\mathrm{v}$ charakteristice záměrů jednotlivých semestrů studia. (3) Bylo provedeno stanovení analytických kritérií. Významové jednotky vycházejí z teorie výzkumného problému, tj. charakteristiky profesního učení studentů při osvojování profese učitelství pro primární vzdělávání, mezi 
které patří např. pojetí žáka, pojetí výuky, profesní sebepojetí. (4) Studentům byl zadán úkol, aby se pokusili o písemné reflexe uspořádání ukázkového portfolia $\mathrm{z}$ pěti hledisek, které vyplynuly $\mathrm{z}$ před-výzkumné strategie analýzy profesních portfolií.

Jde o prrípadovou studii studentského portfolia studentů jedné studijní skupiny 5. ročníku studijního oboru Učitelství pro 1. stupeň základní školy. Případová studie jako výzkumná strategie by měla splňovat nejméně tři charakteristiky (Švař́iček, Šed’ová et al., 2014, s. 97-98 podle Yin, 2003, s. 13-14): (1) jde o integrovaný systém, $v$ našem př́ípadě o studenty jedné studijní skupiny, který je časově i prostorově vymezen hranicemi; (2) komplexní porozumění případu probíhá $\mathrm{v}$ přirozeném prostředí, kde jsou sledovány interakce mezi prípadem a okolím studentů při osvojování učitelské profese; (3) jsou využívány všechny dostupné zdroje i metody sběru dat (portfolia - dokumenty, analýza ukázkové reflexe profesního učení, rozhovory, hodnocení přínosu pro profesní učení). Z hlediska typu př́padové studie můžeme konstatovat, že se jedná o př́pad s vloženými jednotkami analýzy (Hendl \& Remr, 2017, s. 203) - jedná se o studentské portfolio $s$ jednotkami obsahové analýzy více studentských reflexí.

V kvalitativní strategii empirického výzkumu byl sledován princip triangulace metod sběru dat. Obsahová analýza psaných textů reflexe studentského portfolia byla kombinována $s$ ústní prezentací na seminářích (únor až duben 2021) a nestrukturovaným rozhovorem po kaž- dé studentské prezentaci výsledků reflexe (komunikací přes systém Teams).

Postup při zpracovávání dat výsledků výzkumu byl následující. Studentky byly požádány, aby písemně formulovaly reflexi částí ukázkového portfolia a uspořádaly je do následujících pěti hledisek:

- Reflexe v oblasti pedagogické: Zhodnotit prrínos studia pedagogické teorie pro vlastní profesní učení. Jaké byly zaznamenány pokroky $v$ profesnim učeni z blediska zpracovaných seminárnich praci?

- Reflexe v oblasti pedagogické praxe protokoly z pozorování: Zhodnocení př́nosu pedagogické praxe pro vlastní profesní učení. Co jsem se naučila pozorováním výuky?

- Reflexe v oblasti pedagogické praxe protokoly z vlastních výstupů: Zhodnocení přínosu výukové pedagogické praxe pro vlastní profesní učení. Co jsem se naucila prípravou, realizací a reflexí vlastnich pokusů vyučovat?

- Reflexe závěrečné pedagogická praxe (u studentů 5. ročníku): Jaká je celková reflexe prìnosu závèrečné sestitýdenni pedagogické praxe pro profesni učeni z hlediska propojení odborné teorie a praxe?

- Reflexe celkového prínosu profesního učení: Co jsem se naucila z hlediska propojeni teoretické a praktické složky studia? Zpracování výsledků bylo provedeno kvalitativním postupem. Byly vybrány reprezentativní formulace studentů pro jednotlivé okruhy reflexí a $v$ nich hledány společné jmenovatele pro klíčové znaky profesního učitelského učení studentů, pomocí nichž lze zformulovat odpovědi na výzkumné otázky $\mathrm{v}$ klíčových katego- 
riích. Jednou ze strategií pro kvalitativní vyhodnocení dat je podle Hendla a Remla $(2017$, s. 216) otázka Jaké názory mají participanti na predmèt výzkumu?, v našem príípadě na své vlastní profesní učení. Klíčové podkategorie a kategorie tvoří základní strukturu pro uspořádání výsledků rozboru písemné reflexe studia ve výzkumném šetření - viz výsledky a jejich interpretace.

\subsection{Vzorek výzkumu}

Předmětem obsahové analýzy byla studentská portfolia tř́ ročníků studia Učitelství pro 1. stupeň základní školy.

\begin{tabular}{|c|c|}
\hline Ročník studia & $\begin{array}{c}\text { Počty studentských } \\
\text { portfolií }\end{array}$ \\
\hline 3. & 37 \\
\hline 4. & 36 \\
\hline 5. & 18 \\
\hline Celkem & $\mathbf{9 1}$ \\
\hline
\end{tabular}

$\mathrm{V}$ předložené studii budou uvedeny vybrané ukázky z formulací reflexí studentského portfolia studentek $\mathrm{v}$ závěrečném, pátém ročníku studia oboru Učitelství pro 1. stupeň základní školy.

Tab. 1 Přehled vložených seminárních prací (VK, $\left.5^{1}\right)$

\begin{tabular}{|l|l|l|}
\hline \multicolumn{3}{|c|}{ Přehled napsaných teoretických seminárních prací podle ročníků a semestrů } \\
\hline & \multicolumn{1}{|c|}{ Zimní semestr } & \multicolumn{1}{c|}{ Letní semestr } \\
\hline 1. ročník & $\begin{array}{l}\text { Jaký existuje vztah mezi } \\
\text { hudebními a jinými speciálními } \\
\text { schopnostmi u dítěte na základní } \\
\text { škole? }\end{array}$ & $\begin{array}{l}\text { Hodnotové zaměrení ve vybraných } \\
\text { školských vzdělávacích } \\
\text { programech. }\end{array}$ \\
\hline 2. ročník & $\begin{array}{l}\text { Jak se změnila dramatická } \\
\text { výchova v rámci kurikula } \\
\text { primární školy po roce 1989? }\end{array}$ & $\begin{array}{l}\text { Jaké emoční problémy můžeme } \\
\text { diagnostikovat v souvislosti } \\
\text { s negativními emocemi v životě } \\
\text { žáka? }\end{array}$ \\
\hline 3. ročník & $\begin{array}{l}\text { Jaké pojetí pedocentrismu } \\
\text { mǔžeme vidět ve vybraných } \\
\text { alternativních pedagogikách? }\end{array}$ & $\begin{array}{l}\text { Učitelské zdraví - profesní } \\
\text { kondice. }\end{array}$ \\
\hline 5. ročńník & $\begin{array}{l}\text { Proces výuky: projektování, řízení } \\
\text { a reflexe. }\end{array}$ & $\begin{array}{l}\text { Pedagogický projekt: Proč existují } \\
\text { zvuky? }\end{array}$ \\
\hline $\begin{array}{l}\text { Pedagogický problém: } \\
\text { Jaké projevy neverbální } \\
\text { komunikace múžeme } \\
\text { identifikovat u učitele } \\
\text { primárního vzdélávání? }\end{array}$ & \\
\hline
\end{tabular}

${ }^{1}$ Student VK, 5. ročník (označení studentů dále v textu tvořeno analogicky). 


\subsection{Výsledky výzkumu a jejich interpretace}

Výsledky výzkumu jsou uspořádány ve vztahu $\mathrm{k}$ okruhům položených výzkumných otázek. Jaké typy produktů studia pedagogiky studenti vkládají do individuálních portfolií? Tabulka 1 je vybrána jako reprezentující př́lklad individuální trajektorie volby produktů studentů (seminárních prací), které byly vkládány do studentského portfolia $\mathrm{v}$ průběhu pěti let.

Výzkumná kategorie č. 1: Pedagogická teorie pro mě (podkategorie: objevení teorie jako nové opory, porozumění sobě - své zkušenosti, nový pohled na žáky, vhled do procesů výuky)

Nyni, když jsem $v$ pátém ročniku a na konci své studijni cesty, musim rici, že mè teoretické poznatky obohatily nejen o teorii, ale psani seminárnich praci mé naucilo organizovanosti nebo spolupráci. Jasně vidím př́nos studia teorie $v$ tom, že nyni, když jsem teoreticky zásobená, umim teorii využit $v$ praxi a je to mnohem jednodušsí, než to bylo napríklad ve tretím ročniku. Stále hlubšim pronikánim do teoretické problematiky jsem začala oceňovat zásadni význam pedagogické teorie pro pedagogickou praxi. Umožňuje mi totiž pronikat do podstaty, do vnitrnich zákonitostí pedagogické praxe a osvètluje mi tak cestu $k$ vlastni tvorivé vzdélávací cinnosti. $(\mathrm{KS}, 5)$

... ačkoliv byly v̌́echny seminárni práce velmi obsáblé, pomohlo mi to proniknout $k$ radě základnich pojmü, kde si myslim, že jsem vybudovala natolik pevné stavební kameny, na nichž můžu stavit dodnes... $(\mathrm{BP}, 5)$

Když zavzpominám na mé začátky zpracováváni seminárnich praci, vybavi se mi, jak jsem se ucila pracovat se zdroji a citacemi, se kterými jsem do té doby méla minimálni zkušenosti. Mèla jsem možnost pracovat jak s odbornými časopisy, monografiemi č publikacemi. $(\mathrm{KK}, 5)$

Nakonec musim rict, že vypracováni seminárnich práci a studium pedagogické teorie beru jako podstatnou a neoddèlitelnou ćást pro výkon profese učitele. Nyni si už nedokážu predstavit, že bych o realitě ve školnim prostředi vlastnè nic nevédèla a šla učit. Nyni už vím, že člověk opravdu potřbuje znát:

- sebe jako učitele s veškerou zodpovědností

- žáka jako lidskou bytost s emocemi, svým vlastnim hodnotovým žebričkem, či individuálni úrovni rozvinutých schopnosti

- proces výuky - možnosti spojené s plánovánim, rizenim a hodnocenim výuky. $(\mathrm{VK}, 5)$

Typy produktů ve studentském portfoliu odrážejí individuální trajektorii osvojování pedagogické teorie. Studentky poukázaly na objevení smyslu osvojování teorie pro ovlivňování edukační reality.

Výzkumná kategorie č. 2: Pozorování je východiskem (podkategorie: inspirace od zkušených učitelů, povzbuzení od žáků, aktivizující metody, vlastní identita, atmosféra, klima) 
Tab. 2 Přehled realizovaných pozorování výuky $(\mathrm{VB}, 5)$

\begin{tabular}{|c|c|c|}
\hline \multicolumn{3}{|c|}{ Přehled uskutečněných pozorování uspořádaných podle ročníků a semestrů } \\
\hline & Zimní semestr & Letní semestr \\
\hline \multirow[t]{4}{*}{ 1. ročník } & \multirow[t]{4}{*}{$\begin{array}{l}\text { Pedagogika } \\
10 \text { pozorování (realizace } \\
5 \text { pedagogických úkoli̊) }\end{array}$} & $\begin{array}{l}\text { Pedagogika } \\
3 \text { pozorování + } 1 \text { pozorování zápisu } \\
\text { do školy }\end{array}$ \\
\hline & & $\begin{array}{l}\text { Psychomotorika } \\
1 \text { pozorování }\end{array}$ \\
\hline & & $\begin{array}{l}\text { Psychologie osobnosti } \\
1 \text { pozorování }\end{array}$ \\
\hline & & $\begin{array}{l}\text { Didaktika anglického jazyka } \\
\text { a literatury } \mathbf{v} \text { primárním vzdělávání } 1 \\
1 \text { pozorování }\end{array}$ \\
\hline \multirow[t]{3}{*}{ 2. ročník } & $\begin{array}{l}\text { Pedagogika } \\
4 \text { pozorování ( } 6 \text { pozorovacích } \\
\text { úkolů) }\end{array}$ & $\begin{array}{l}\text { Pedagogika } \\
10 \text { pozorovaných hodin (realizace } \\
5 \text { úkolů) }\end{array}$ \\
\hline & \multirow[t]{2}{*}{$\begin{array}{l}\text { Společenskovědní vzdělávání } \\
1 \text { pozorování }\end{array}$} & $\begin{array}{l}\text { Didaktika přírodovědného } \\
\text { vzdělávání } \\
5 \text { pozorování }\end{array}$ \\
\hline & & $\begin{array}{l}\text { Didaktika rozvoje čtení a psaní } \\
2 \text { pozorování }\end{array}$ \\
\hline \multirow[t]{2}{*}{ 3. ročník } & \multirow{2}{*}{$\begin{array}{l}\text { Didaktika matematiky } \\
\mathbf{s} \text { praxí } 1 \\
3 \text { pozorování }\end{array}$} & $\begin{array}{l}\text { Didaktika mateřského jazyka } 1 \\
7 \text { pozorování }\end{array}$ \\
\hline & & $\begin{array}{l}\text { Didaktika matematiky s praxí } 2 \\
2 \text { pozorování }\end{array}$ \\
\hline 4. ročník & \multicolumn{2}{|c|}{ Pozorování neproběhla, protože probíhaly vlastní pokusy vyučovat. } \\
\hline 5. ročník & $\begin{array}{l}\text { Souvislá praxe } \\
20 \text { pozorování }\end{array}$ & \\
\hline
\end{tabular}

$\mathrm{V}$ tabulce 2 byl studentkou uspořádán podklad, který dokumentuje reflexi náslechové pedagogické praxe. Přehled protokolů $\mathrm{z}$ pozorování podle ročníku a semestrů: až 60-75 pozorování celkem $\mathrm{v}$ průměru všech reflexí. Všechna pozorování jsou doložena pozorovacími protokoly a mohou být inspirací $\mathrm{k}$ následným vlastním pokusům vyučovat.
Vidèla jsem skvělé učitele, kteři mé inspirovali pro mou budouci praxi. Ale také jsem pozorovala ucitele, kde jsem si uvědomila, že nezastávám stejný postoj $k$ výuce či žákưm jako pozorovaný učitel. Diky tomu, že jsem méla možnost vidèt rüzné učitele $v$ praxi, utvorila jsem si predstavu o tom, jaká uci $i$ telka bych chtéla být já. Diky pozorováni se mi můj obraz o budouci praxi stále dotvárel 
a uvědomovala jsem si náročnost této profese. Ale zároveñ jsem viděla radost a uspokojení. I když tato práce někdy vyžaduje hodně sil, žáci dokáži několikanásobnè vrátit energii a chut'zpèt do práce. (VH,5)

Prímým pozorováním učitele jsem se naučila, jak je vhodné s žáky ve výuce komunikovat, jaké jsou možnosti organizace žáki $i$ samotné výuky, poznala jsem také radu podnètných metod a aktivit do výuky. Zároveñ jsem však vnimala, že se do jisté miry utvárí také má učitelská identita... (VK,5)

Bylo vidèt, že se daleko více soustredim na trídu globálně a jsem schopná odhadnout aktuálni atmosféru, a pokud ve trídě zuistáváme vice pozorovacich hodin, tak i klima. (BP,5)

$Z$ předchozích formulací studentek je zřejmé, že oceňují mnoho př́ležitostí k pozorování, jež měly možnost uskutečnit. Uvádějí, že získaly inspiraci k vlastnímu řešení výukových situací od zkušených učitelů. Také pozorovaly povzbuzení ze strany žáků, když jim byly dány příležitosti k aktivnímu učení. Studentky obohatily své sebevědomí a hlouběji se identifikovaly s učitelskou profesí. Cítily prohloubení svého citu pro atmosféru a klima školní tř́ídy.

Výzkumná kategorie č. 3: Tvoření výuky (podkategorie: komunikace s žáky, respektování žáků, úcta $\mathbf{k}$ uvádějícím učitelům praxe, reflexe tvoření ve výchovách, zvládání nervozity)

Následující výroky studentek vybrané z portfolia reprezentují, jaké reflexe studenti formulují vzhledem ke svým vlastním pokusům vyučovat.
Diky vlastnim výstupuim jsem se naučila, jak vystupovat pred žáky a jak s nimi komunikovat a pracovat. Naučila jsem se odhadnout ćas aktivity podle tempa práce žákì. V některých výstupech jsem se ponaučila, že ne vždy se dá stibnout to, co si naplánuji. A nemělo by mi jit jen o to, abych stibla vše podle prípravy. Je dìležité hodinu prizpiosobit žákim, podle toho, co potrebuji. Svými výstupy jsem se také naučila, že je dobré mit vždy v záloze aktivity pro žáky, kteři jsou v práci rychlejši než ostatni żáci. $(\mathrm{VH}, 5)$

Také jsme mély zejména didaktiky rüzných výchov, takže jsem si poprvé zkusila učit hudebni, tèlesnou a výtvarnou výchovu. Ukázalo se, že mi jsou tyto predmèty velmi blizké, ale jejich príprava nebyla o nic snazši než v minulých semestrech. Nejvètšim úspèchem pro mè byla výuka hudebni výchovy, což je také znát na mých protokolech. (BP, 5)

Jsem si jistá, že jsem za dobu svého studia ušla kus velké cesty. Prvnè bych chtěla zminit nervozitu, která se objevila pred každým prvnim pokusem vyučovat a s každým dalšim výstupem se postupně snižovala. Jsem znovu vděčná za možnost si tolikrát zkusit vést třidu během prüběžných praxí. Jak už jsem zmiňovala u reflexe pozorováni, s každým dalsím semestrem pribývaly kategorie, které jsme se naučily a mohly je tak začit zohledñovat do výuky. Vim, že s každým dalšim semestrem ve mnè rostl $i$ zájem o żáky a začala jsem vždy premýślet o dìvodech, co vedlo $k$ reakci toho ditète. Jak jinak pomoci ditèti se specifickou potrebou atd. Nebo jednoduše, jak udělat výuku ještě zajimavèjši. Neř́kám, že ted' jsem zcela bez nervozity, 
ale myslim, že v některých předmètech užji mám mnohem méně než dř̀v. (AV,5)

Přehled protokolů vlastních výstupů studentů podle ročníků a semestrů zahrnuje 44-46 vlastních výstupů. Pokusy vyučovat jsou zachyceny $\mathrm{v}$ protokolech ve studentském portfoliu a jsou podkladem ke státní závěrečné zkoušce. Studentky konstatovaly, že prohloubily vnímání pedagogické komunikace a interakce při realizování vlastní výuky. Pomáhalo jim respektování žáků a projevy úcty z jejich strany. Studentky projevily obdiv k uvádějícím učitelům, kteří jim nechávali prostor pro vlastní tvorbu výuky a řešení nečekaných situací. Mohly postupně odbourávat svoji nervozitu a překonávat nejistotu.

\section{Výzkumná kategorie č. 4: Aktérem ces-} ty k profesi (podkategorie: vlastní návrhy a nápady, nezůstat laikem, pokusy vyučovat od začátku studia, ověřování teorie, respektování vzdělávacích dokumentů, spolupráce)

V následujících ukázkách bude uvedeno, jaké názory k osvojování učitelské profese lze u studentů identifikovat v portfoliu z hlediska podílu jejich vlastního aktérství v profesním učení.

Již $v$ pronim ročniku jsme aktivně nastoupili do základnich škol na praxe. $\mathrm{Na}$ tuto zkušenost pamatuji s rüznými emocemi, jak s obavami (které však postupně odcházely), tak s velkým očekáváním toho, co nás čeká. Jako prázdná nádoba jsem se již $v$ tomto obdobi ( $v 1$. ročniku studia) začinala rüznými podnéty a zkušenostmi plnit, a tomu pomáhaly jisté teoretické poznatky, tak také samotná praxe, která však našla ve mně jako nádobě jistě silnějš́ opodstatnění. Obecně můžu už nyni ríct, že v̌̌e, co bylo u mne spojeno s určitou interakci (a to jak pri osvojováni pedagogické teorie, tak $v$ rámci praxe), se mi vice vrylo pod kưži.

Uprímně si nedokážu predstavit skutečnost, že bych si osvojovala pedagogickou teorii, a pritom nevéděla, jak ve skutečnosti funguje školni vyučováni, jak vypadá práce učitele atd. Jsem vděčná, že v prüběhu celého studia jsem mohla v̌̌e, co mi bylo řečeno $v$ pedagogické teorii, do jisté miry "prověrovat" $v$ pedagogické praxi. At' už v rámci svého pozorováni, či samotných výstupi diky tomu jsem si také formulovala postupnè své názory a postoje $k$ informacím, jež nám byly $v$ rámci pedagogické teorie sdélovány. $(\mathrm{VK}, 5)$

Pokud bych méla zhodnotit prínos propojeni pedagogické praxe s teorii, tak bych rekla, že obzvláštè u oboru Ućitelství pro 1. stupeñ $Z S$ je to opravdu velmi düležité. Bez teorie bychom nemohly jit do praxe s tim, že jsme dobre vybaveni pro učitelskou profesi. Nyni si to uvédomuji mnohem vice, než tomu bylo v pronim ročníku. Myslim si, že pokud bych mèla pouze praxi, tak bych se pravdèpodobnè naučila, jak žáky něcemu naučit, ale pouze na základě pozorováni kvalifikovaných učitelek. Zcela určitè nelze učit dèti bez znalosti odborných věcí a nejde odtrhnout teorii od praxe a obrácenè. Byla bych pouze laikem, který si hraje na ucitelku. Bez studia teorie bych nerozuméla odborným pojmuim, nevédèla bych, jak $k$ dètem pristupovat, jaké možnosti, metody, postupy volit ve vyucování. A to už vỉbec nemluvim o tom, že bych neměla žádné 
znalosti z oblasti pedagogiky, psychologie, didaktiky atd. Nedokázala bych si správnè nastavit cile, kompetence, pracovat s $R V P Z V$, $\check{S} V P$, provádèt správnou diagnostiku žákì, třidy, hodnotit dèti, provádèt sebehodnoceni aj. Možná bych si ani neuvédomila věci, které se mi nyni zdaji samozrejmé, a to jen diky teorii, kterou jsem studovala. Teorie mi dala širokou nabidku toho, jak se můžu ujmout praxe. Diky teorii jsem se dozvěděla, jak vlastnè pracovat v praxi. Praxe mi zase naopak potvrdila, že pokud bych neméla dostatečné znalosti, jak pracovat s détmi, jak $k$ nim pristupovat, jaké zásady dodržovat, tak bych nemohla ríct, že vyučuji dobře.

Je opravdu dìležité propojeni teorie $s$ praxi a vidèt smysl $v$ učeni se teorie. Jsem ráda za to, že jsme mély praxi už od prvního ročniku a proni pokusy o učeni již ve druhém ročníku. Pamatuji si, že tehdy se mi to nezdálo jako dobrý nápad. Ale teprve až ted' zpètně to dokážu ocenit. Společnè s vyučujicimi jsme rozebiraly jednotlivé prípravy a výstupy a na tom jsme si uvédomovaly, jak jinak by šla daná hodina zpracovat a jak žákưm dané učivo predat. Mohly jsme své prípravy a výstupy rozebirat nejen s vyučujicimi, ale i se svými kolegynèmi a navzájem se tak i inspirovat, motivovat. $(\mathrm{KK}, 5)$

Během závérečné praxe, kdy jsem se na tèch 6 týdnù presunula do jiného prostredi mezi žáky a byla jsem v roli učitele, tak mě to velice bavilo a naplňovalo, avšak to bylo online prostředi, všechno jsme hravě zvládli. Mèla jsem tu čest setkat se s pani učitelkou, která má za sebou dlouholetou praxi a hodnè vècí jsem se od ní naučila. (LB,5)

Studentky velmi ocenily, že dostaly př́ležitost být aktérem vlastního profesní- ho učení. Za hodnotné označily respektování jejich vlastních názorů a nápadů při spolupráci s učiteli i kolegyněmi.

Dlouhodobost prrípravy studentů učitelství v magisterských programech je stále diskutována vzdělávací politikou, aniž by se vždy opírala o výzkumná data. Výroky studentek v hodnoticím portfoliu jsou jedním z důkazů, které demonstrují blahodárnost zrání profesního učení a profesní identity, jež studentky samy objevovaly.

Závěrečná praxe probíhala $\mathrm{v}$ covidovém období a prověrila profesní připravenost studentek, které musely přizpůsobit vše zcela novým podmínkám spolu s vyučujícími pedagogických praxí ve školách. Studentky reflektují to, že obstály. Některé z nich obdržely i nabídku pracovního místa po zakončení studia. Studentky projevily potence $\mathrm{k}$ pedagogické tvořivosti, ke které byly vedeny od začátku studia tím, že vstupovaly do programu studia jako aktérky.

\subsection{Diskuse k výsledkům empirického výzkumu}

$\mathrm{Na}$ význam procesu dlouhodobého profesního zrání a individuálního profesního sebepojetí mnohokrát upozornila v minulosti celá řada autorů v Česku (Spilková, Mareš, Lukášová-Kantorková, Tomková, Píšová, Svatoš, Gavora, Wiegerová, Švec, Vašutová, Stuchlíková a Janík) i v zahraničí (Roche, Marsh, Yough). Svatoš už v roce 2006 výzkumně doložil, že „právě portfolio by mohlo být vhodným instrumentem, který umožní poznávat 
individuální trajektorie profesionalizujícího se jedince“. Což bylo od té doby mnohokrát potvrzeno pedagogickým výzkumem.

Formulace studentek pátého ročníku jednoznačně ocenily př́nos dlouhodobé cesty učení se profesi učitelství, i když ji někdy popisují jako velmi náročnou. $\mathrm{V}$ produktech, které byly do portfolia vloženy, je možné identifikovat kvalitativní obraz cesty při osvojování profese učitelství.

Konstrukt sebepojetí (self-concept) v pozitivním smyslu je často vnímán jako hlavní cíl sám o sobě a často se na něj pohlíží jako na důležitý faktor, který může pozitivně ovlivnit požadované výsledky učitelského studia $\mathrm{v}$ různých kontextech, tudíž i v prostředí vzdělávání (Roche \& Marsh, 2000; Gavora et al., 2020). Autoři dále tvrdí, že sebepojetí je ovlivněno hodnocením od osob, které jsou pro jedince důležité, a také zkušenostmi a interpretací okolí. Vzniká tak potřeba pocitu naplnění (fulfillment) připravenosti $\mathrm{k}$ profesi, která nastavuje významné parametry u subjektivní odpovědnosti studentů učitelství (viz Yough et al. in Pečivová, 2021).

Celá řada studentských formulací reflexí je důkazem, že potřeba pocitu naplnění připravenosti $k$ výkonu učitelské profese byla skutečným průvodním znakem popisu profesního učení ve studentském portfoliu. Byla oceněna partnerská zpětná vazba od kolegyň ve studijní skupině i od učitelů pedagogických praxí.

Výzkum vnímáním svého profesního růstu a sebepojetí u studentů učitelství realizovali např́íklad Kratochvílová a Lojdová (2019), Kratochvílová a Horká
(2016), Pravdová (2014, 2015). Pravdová (2014) považuje pozitivní sebepojetí učitele a jeho rozvoj za velmi důležité a uvádí, že pokud je učitel „... schopen respektovat sám sebe nejen jako osobnost, ale i jako profesionála, je motivován $\mathrm{k}$ trvalému sebezlepšování a profesnímu růstu“ (Pravdová, 2014, s. 181). Podle autorky pozitivní profesní pojetí učitele podmiňuje úspěšný výkon pedagogické profese.

Pozitivní profesní sebepojetí můžeme číst ze všech analyzovaných studentských portfolií. To nevylučuje ani skutečnost, kdy studentky líčí zaváhání a pochybnosti. Kladou si otázku, zda budou jejich sily stačit na výkon všech nároků profese učitelství, jak se před nimi objevovaly v průběhu studia. Studentky si kladou otázky $\mathrm{k}$ vlastnímu aktérství a tvořivosti.

Svatoš (in Gavora et al., 2020, s. 53-55) rozděluje dobu studia na několik vývojových fází: etapa adaptační - začínající studenti učitelství; etapa první redefinice role - sociálně-osobnostní; etapa druhé redefinice role - didakticko-reflexivní a výkonová; etapa kompetentní - absolvent studia. Z hlediska uvedených fází prochází studentky všemi kroky odborné př́pravy, které nacházíme v dostupné literatuře. $\mathrm{V}$ tomto textu jsme věnovali pozornost jednotlivým fázím především z hlediska propojenosti pedagogické teorie a pedagogické praxe $\mathrm{v}$ programu učitelské př́pravy pro primární edukaci, jak je zachyceno v jejich individuálních portfoliích.

Ukázalo se, že studentky ve výzkumném vzorku oceňují vlastní aktérství pro osvojování učitelské profese a jsou schopny pojmenovat i celkový komplexní prínos 
studia pro své profesní učitelské učení jak z hlediska rozvoje vlastních odborných názorů, tak z hlediska růstu vlastní profesní identity.

Studentské formulace v reflexi portfolia jasně dokládají náročnost studia učitelství v oblasti akademických základů širokého spektra pedagogicko-psychologických věd (viz také Tomková, 2004, 2018; Lukášová, 2015; Kratochvílová \& Lojdová, 2019; Spilková, 2019b; Starý et al., 2012; Wiegerová, 2015; Stará \& Wildová, 2020). Učitelskou prŕpravu nelze redukovat na výcvikové kurzy, na pouhou pedagogickou praxi zaměřený trénink $\mathrm{v}$ profesně redukovaném modelu, jenž se opírá o neoliberální tendence $\mathrm{v}$ př́stupech $\mathrm{k}$ vysokoškolskému univerzitnímu vzdělávání $\mathrm{v}$ posledním desetiletí (viz také Liessmann, 2008; Štech, 2007, 2014; Kaščák \& Pupala, 2012; Kosová, 2013; Spilková, 2019a). Autorky Spilková (2019a), Kratochvílová a Lojdová (2019) formulují principy, o něž by se změny učitelské prrípravy mohly opírat a které mohou být velmi konkrétními podněty pro vzdělávací politiku do budoucna; provedený pedagogický výzkum přináší další argumenty pro cestu ke kvalitě v tomto směru.

Potvrzujeme i naším výzkumem, že student učitelství se může stát subjektem - aktérem vlastního profesního učení při osvojování učitelství, jestliže $\mathrm{k}$ tomu má odpovídající vedení a vhodné podmínky, které by vzdělávací politika mohla $\mathrm{v}$ budoucnu podpořit ve směrech, které budou formulovány na základě dat výzkumu v následujícím závěru.

\section{LIMITY VÝZKUMU}

Hlavním limitem prezentace výsledků kvalitativního výzkumu je rozsah studie umožňující vložit jen vybrané ukázky rozsáhlé analýzy studentských portfolií, které studentky samy provedly.

Dalším limitem byla redukovaná možnost komunikace se studentkami, autorkami reflexí portfolií, která mohla probíhat jen elektronickou formou rozhovorů přes systém Teams nad výsledky reflexe $\mathrm{v}$ době pandemie.

\section{ZÁVĚRY}

$\mathrm{Na}$ závěr se pokusíme zhodnotit, $\mathrm{v}$ jaké podobě byly naplněny záměry empirického výzkumu $\mathrm{k}$ posouzení kroků profesního učení se učitelství u studentů a co o reflexi cesty $\mathrm{k}$ učitelství bylo možné číst ve studentských portfoliích.

$\mathrm{Z}$ výsledů provedeného pedagogického výzkumu reflexe ukázkového studentského portfolia bylo možné zjistit, jaké produkty studia pedagogiky vkládají studenti do individuálních portfolií během všech semestrů studia. Ukázky reprezentují individuální uchopení vědního pedagogického základu učitelské profese $\mathrm{v}$ reflektivním modelu a ocenění reflexí pedagogické praxe z hledisek osvojené pedagogické teorie ve vztahu $\mathrm{k}$ realizované pedagogické praxi.

Ukázalo se, že studentské portfolio je cenným nástrojem, který studentům umožňuje uspořádat si v sumě až $60-70$ pozorování výuky a sestavit $40-50$ vlastních pokusů vyučovat ve škole na 1 . stupni základní školy. V reflexích studentek je vi- 
dět oceňování všech možností propojení pedagogické teorie a praxe. Komunikace $s$ mentory praxe $\mathrm{v}$ základních školách i s kolegyněmi ve studijní skupině umožňuje studentkám získání otevřenosti pro odbornou zpětnou vazbu. Oceňovány jsou i kritické postoje, které se studentky naučily přijímat jako podněty pro své profesní učitelské učení a díky kterým si vyzkoušely odolnost vůči kritickým postřehům.

Výsledky nás vedou $\mathrm{k}$ doporučení, aby bylo realizováno dlouhodobé profesní studium učitelství, které umožní profesní zrání a reflektivní charakter osvojování učitelské profese.

Doufáme, že uvedené podněty a výsledky výzkumu studentského profesního učení, které jsou demonstrovány v profesním portfoliu, mohou být důležitým podnětem $\mathrm{k}$ uvažování o kvalifikovanosti uchazečů pro učitelskou profesi. Výsledky výzkumu studentského portfolia dokládají, že může být dobrým základem pro ukázkový dokument, který s sebou mohou studentky přinášet pro situace přijímání do profese v základní škole. Do budoucna by tento dokument mohl být kvalitním důkazem profesní učitelské př́ípravy, o který se může zajímat i vzdělávací politika při stanovování kvalitativních nároků na uchazeče o výkon profese. Studentské portfolio ukazuje výsledky, ale i reflexi všech fází procesu profesního učení na cestě $\mathrm{k}$ učitelské profesi. Zachycuje aktérství studentek při objevování smyslu pedagogické teorie pro pedagogickou praxi, oceňování průběžných praxí pro profesní inspiraci vlastní cesty, kritický náhled na vlastní první pokusy vyučovat.

Pro posuzovatele programů, které deklarují učitelskou prŕípravu, bude dů- ležité rozpoznat, zda je $\mathrm{v}$ nich identifikovatelný proces profesního učení, který vede od subjektivních studentských prekonceptů o výchově, vzdělávání a výuce $\mathrm{k}$ vědecké pedagogické teorii a praxi. Ve studentském portfoliu můžeme uvidět i obraz myšlenkového pohybu studentů v profesním učení od pedagogické teorie $\mathrm{k}$ aplikaci ve vlastní pedagogické praxi a prŕípravách na vlastní pokusy vyučovat. $\mathrm{V}$ nich mohou být průběžně zakomponovány kvalitní profesní sebereflexe, jež mohou dokumentovat proces průběžného osvojování profesní učitelské identity.

$\mathrm{Na}$ úplný závěr zformulujeme alespoň tři doporučení pro vzdělávací politiku, která vyplývají ze získaných výzkumných dat pedagogického výzkumu:

(1) Preferovat dlouhodobé pětileté programy pro učitelské vzdělávání, aby student měl odpovídající časový prostor pro profesní učení a vývoj individuálního profesního sebepojetí.

(2) Sledovat, zda navržený program učitelské př́pravy respektuje všechny kvality profesního zrání, zda je zařazena vstupní reflexe prekoncepů a miskonceptů pojetí výchovy, vzdělávání a výuky. Prověrit, zda student učitelství je pojat jako aktér vlastního profesního učení a je schopen sebereflexe cesty $\mathrm{k}$ profesi během studia a svého profesního sebepojetí.

(3) Posoudit, zda projekt učitelské prýipravy obsahuje prostor pro hodnocení a sebehodnocení studentů $\mathrm{z}$ hlediska kvality cesty $\mathbf{k}$ učitelské profesi a zda program prŕpravy zavádí studentské portfolio jako doklad o individuální kvalitě a trajektoriích profesního učení a seberozvoje. 


\section{LiterATURA}

ATEE (2006). The Quality of Teachers. Policy paper - Recommendation on the development of indicators to identify teacher quality. Amsterdam: Associacion for Teacher Education in Europe.

Atkinson, T., \& Glaxton, G. (Eds.). (2001). The Intuitive Practitionar on the value of not always knowing what one is doing. Buckingham-Philadelphia: Open University Press.

Doušková, A. (2007). Portfólio a profesná prax. In M. Píšová (Ed.), Portfolio v profesní prípravě učitele (s. 75-80). Pardubice: Fakulta humanitních studií Univerzity Pardubice.

Doušková, A., \& Porubský, Š. (Eds.). (2011). Problémy a perspektivy primárnej edukácie. Banská Bystrica.

Eliot, J. (Ed). (1993). Reconstructing teacher education - teacher development. Great Britain: Burgess Scient Press.

Gavora, P. (2000). Úvod do pedagogického výzkumu. Brno: Paido.

Gavora, P., \& Mareš, J., Svatoš, T., \& Wiegerová, A. (2020). Self efficacy v edukačnich souvislostech II. Zlín: Fakulta humanitních studií UTB.

Havel, J., \& Filová, H. (2007). Portfolio v pregraduální přípravě učitele primární školy. In M. Píšová (Ed.), Portfolio v profesni prípravě učitele (s. 93-97). Pardubice: Fakulta humanitních studií Univerzity Pardubice.

Heller, J. I., Sheingold, K., \& Myford, C. M. (1998). Reasoning about evidence in portfolios: Cognitive foundation for valid and reliable assessment. Education Assessment, 5, 5-40.

Helus, Z. (2008). Teoretická východiska pojetí učitele v době měnících se nároků na školu a vzdělávání. In V. Spilková \& J. Vašutová (Eds.), Učitelská profese v měnících se podmínkách vzděláváni (s. 11-28). Praha: Pedagogická fakulta UK.

Helus, Z. (2010). Politický, společensko-kulturní a duchovní kontext současného učitelství: důsledky pro pojetí profese. In H. Krykorková, R. Váňová et al., Učitel v současné škole (s. 23-31). Praha: Filozofická fakulta UK.

Hendl, J., \& Reml, J. (2017). Metody výzkumu a evaluace. Praha: Portál.

Janík, T., Maňák, J., \& Knecht, P. (2009). Cíle a obsahy školního vzděláváni a metodologie jejich utváreni. Brno: Paido.

Kasáčová, B. (2005). Reflexivna výučba a reflexia v učitel'skej př́pravě. Banská Bystrica: Pedagogická fakulta UMB.

Kašćák, O., \& Pupala, B. (2012). Škola zatých golierov: vzdelavanie v ére neoliberalizmu. Praha: SLON.

Kennet, W. (1996). Developping an effective teaching portfolio. Educational Leadership, 53(6), 34-37.

Klenowski, V. (2004). Developing portfolios for learning and assessment. New York: Routledge Falmer.

Korthagen, F., Kessels, J., Koster, B., Lagerwerf, B., \& Wubbels, T. (2011). Jak spojit praxi s teorií: Didaktika realistického vzdèláváni učitelů. Brno: Paido. 
Kosová, B. et al. (2012). Vysokoškolskévzdelávanie učitel’ov - Vývoj, analýza, perspektívy. Banská Bystrica: Pedagogická fakulta UMB.

Kosová, B. (2013). Vysokoškolské vzdelávanie učitel'ov na Slovensku. Pedagogika, 63(4), 485-500.

Kosová, B., \& Porubský, Š. (2011). Transformačné premeny slovenského školstva po roku 1989. Banská Bystrica: UMB.

Kratochvílová, J. (2007). Obsahová struktura portfolia. In M. Píšová (Ed.), Portfolio v profesní prípravě učitele (s. 103-107). Pardubice: Fakulta humanitních studií Univerzity Pardubice.

Kratochvílová, J., \& Horká, H. (2007). Promèny učitelského vzdèláváni v kontextu reformy základniho školství. Brno: MSD.

Kratochvílová, J., \& Horká, H. (2016). Autonomní a heteronomní hodnocení jako jedna z determinant účinnosti učitelských praxí. Pedagogická orientace, 26(2), 272-298.

Kratochvílová, J., \& Lojdová, K. (2019). Reforma kurikula pedagogicko-psychologického modulu na Pedagogické fakultě Masarykovy univerzity: Hledání kvality v éře masifikace. Pedagogika, 69(3), 293-315.

Lazarová, B. et al. (2006). Cesty dalšiho vzděláváni učitelù. Brno: Paido.

Liessmann, K. P. (2008). Teorie nevzdělanosti - omyly společnosti vědèní. Praha: Academia.

Lukášová-Kantorková, H. (2003). Učitelská profese v primárním vzděláváni a pedagogická príprava učitelů. Ostrava: Pedagogická fakulta OU.

Lukášová, H. (2004) (ed.). Př́prava učitelì pro primárni vzděláváni ČR budouci scénáre $v$ Evropè. Ostrava: Pedagogická fakulta OU.

Lukášová, H. (2006). Metamorfózy pojetí učitelské přípravy a jejich pedagogický výzkum. Pedagogika, 56(1), 5-18.

Lukášová, H. (2009a). Didaktické znalosti obsahu studentů učitelství v primárním vzdělávání. In T. Janík (Ed.), Možnosti rozvijeni didaktických znalostí obsahu u budoucích učitelù (s. 57-71). Brno: Paido.

Lukášová, H. (2009b). Teorie učitelské profese. In J. Průcha (Ed.), Pedagogická encyklopedie (s. 770-775). Praha: Portál.

Lukášová, H. (2011). Učitelská profese v edukační kultuře obratu. In W. Korzeniwska, A. Murzyn \& H. Kantorková-Lukášová (Eds.), Nauczyciel - wartości - świat [Učitel hodnoty-svět] (sv. 4, s. 89-109). Krakov: Impuls.

Lukášová, H. (2015). Učitelské sebepojetí a jeho zkoumání. Zlín: Fakulta humanitních studií UTB.

Lukášová, H., \& Ries, L. (2010). Učitelství pro první stupeň základní školy. In V. Spilková \& H. Hejlová (Eds.), Príprava učitelů pro primárni a preprimárni vzdèláváni v Česku a na Slovensku (s. 211-231). Praha: Pedagogická fakulta UK.

Lukášová, H., Svatoš, T., \& Majerčíková, J. (2014). Studentské portfolio jako výzkumný prostředek poznáni cesty $k$ učitelstvi. Zlín: Fakulta humanitních studií UTB. 
Lyons, N. et al. (Ed.). (1998). With portfolio in hand: Validating the new teacher professionalism. New York: Teacher College Press.

Mabra, L. (1999). Portfolios plas: A critical guide to alternative assessment. Thousand Oaks: Corwin Press.

Nelešovská, A. et al. (2009). Za kvalitou vzdèláváni učitelů primární a preprimárni pedagogiky. Olomouc: Pedagogická fakulta UP.

Pečivová, V. (2019). Subjective responsibility of Spanish university teachers: A qualitative pilot study. Pedagogika, 69(4), 489-501.

Pečivová, V. (2021). Subjektivni odpovédnost studenti̊ za žáka - kvantitativni a kvalitativní aspekty. (Dizertační práce). Zlín: Fakulta humanitních studií UTB

Píšová, M. (Ed.). (2007). Portfolio v profesni prípravě učitele. Pardubice: Fakulta humanitních studií Univerzity Pardubice.

Píšová, M., \& Duschinská, K. (Eds.). (2011). Mentoring v učitelství. Praha: Pedagogická fakulta UK.

Pravdová, B. (2014). Já jako učitel: profesni sebepojetí studenta učitelství. Brno: Masarykova univerzita.

Pravdová, B. (2015). Chtěná a nechtěná profesní já studentů 2. ročníku pedagogické fakulty. Pedagogika, 67(2), 163-175.

Prokešová, L., \& Stuchlíková, I. (2008). Portfolio studenta učitelství. In J. Vašutová et al., Vzděláváme budoucí učitele (s. 111-135). Praha: Portál.

Roche, L. A., \& Marsh, H. W. (2000). Multiple dimensions of university teacher self-concept. Instructional Science, 28, 439-468.

Snoek, M. (2003). Scenarios for the future of teacher education in Europe. European Journal of Teacher Education, 26(1), 21-36.

Spilková, V. (2004). Současné promèny vzděláváni učitelů. Brno: Paido.

Spilková, V. (2007). Význam portfolia pro profesní rozvoj studentů učitelství. In M. Píšová (Ed.), Portfolio v profesní prípravě učitele (s. 7-20). Pardubice: Fakulta humanitních studií Univerzity Pardubice.

Spilková, V. (2019a). Ke čtvrtstoletí vzniku kateder primární pedagogiky: Reflexe proměn vzdělávání učitelů primárních škol po roce 1989. Pedagogika, 69(3), 365-378.

Spilková, V. (2019b). Přístupy k výuce pedagogiky v kontextu měnících se paradigmat v učitelském vzdělávání. Pedagogika, 69(3), 269-289.

Spilková, V., \& Hejlová, H. (Eds.). (2010). Príprava učitelů pro primární a preprimární vzdèláváni v Česku a na Slovensku. Praha: Pedagogická fakulta UK.

Spilková, V., \& Tomková, A. (Eds.). (2010). Kvalita učitele a profesní standard. Praha: Pedagogická fakulta UK.

Spilková, V., \& Vašutová, J. (Eds.). (2008). Učitelská profese v mènicich se podminkách vzdèlávání. Praha: Pedagogická fakulta UK.

Stará, J., \& Wildová, R. (Eds.). (2020). Changes of pre-primary and primary education. Pedagogika, 70(4), 403-640. 
Starý, K., Dvořák, D., Greger, D., \& Duschinská, K. (2012). Profesni rozvoj učitelů: Podpora učitelů pro zlepšeni výsledkư žákỉ. Praha: Karolinum.

Stuchlíková, I., \& Janík, T. (2017). Rámcová koncepce přípravy učitelů základních a středních škol aneb O hledání a nacházení konsenzu mezi aktéry. Pedagogická orientace, 27(1), 242-265.

Svatoš, T. (2006). Studentské portfolio jako zdroj poznání postojů začínajících studentů učitelství. Pedagogika, 56(1), 45-57.

Svatoš, T., \& Holý, I. (2007). Studentské portfolio v negraduálním učitelském vzdělávání. In M. Píšová (Ed.), Portfolio v profesni prípravě učitele (s. 21-38). Pardubice: Fakulta humanitních studií Univerzity Pardubice.

Štech, S. (2007). Profesionalita učitele v neo-liberální době: Esej o paradoxní situaci učitelství. Pedagogika, 57(4), 326-337.

Štech, S. (2014). Potíže s interpretací změn. Pedagogika, 64(1), 1-4.

Švaříček, R., \& Šed’ová, K. et al. (2014). Kvalitativni výzkum v pedagogických védách. Praha: Portál.

Švec, V. (Ed.). (2005). Od implicitnich teorií výnky $k$ implicitnim pedagogickým znalostem. Brno: Paido.

Švec, V. (2016). Jak se utvářejí tacitní znalosti studentky učitelství Jaroslavy v průběhu její učitelské praxe? In V. Švec, J. Nehyba, P. Svojanovský et al. (2016), Studenti učitelství mezi tacitnimi a explicitnimi znalostmi (s. 169-179). Brno: Pedagogická fakulta MU.

Švec, V., Nehyba, J., Svojanovský, P. et al. (2016). Studenti učitelství mezi tacitními a explicitnimi znalostmi. Brno: Pedagogická fakulta MU.

Tomková, A. (2004). Portfolio v prŕípravě učitelů primární školy. In V. Spilková et al., Současné promèny vzdèlávání učitelù (s. 180-190). Brno: Paido.

Tomková, A. (2018). Portfolio v perspektivě reflektivně pojatého vzdèláváni učitelù. Praha: Pedagogická fakulta UK.

Vašutová, J. (2002). Studentské portfolio. In Strategie výuky ve vysokoškolském vzdělávání (s. 234-239). Praha: Pedagogická fakulta UK.

Vašutová, J. et al. (2008). Vzděláváme budoucí učitele. Praha: Portál.

Vavrus, L. G., \& Collins, A. (1991). Portfolio documentation and assessment center exercises: A marriage made for teacher assessment. Teacher Education Quarterly, 18(3), 13-29.

Wiegerová, A. et al. (2015). Profesionalizace učitele mateřské školy z pohledu reformy kurikula. Zlín: Fakulta humanitních studií UTB.

Yin, R. K. (2003). Case study research: Design and metods. Thousand Oaks: Sage.

Yough, M., Gilmetdinova, A., \& Finney, E. (2020). Teaching the English language learner at the elementary school: Sense of responsibility in an ill-defined role. Journal of Language, Identity \& Education,

prof. PhDr. Hana Lukášová, CSc.,

Univerzita Tomáse Bati ve Zlině, Fakulta humanitnich studií, Ústav školní pedagogiky;

e-mail: hlukasova@utb.cz 


\section{LUKÁŠOVÁ, H. Teachers' Professional Learning and Reflection on Student Portfolios}

The study will show that in recent decades we have been witnessing an ever more urgent search for new ways of evaluating the results of innovated teacher training in Czech and foreign universities. While interpreting the changes, we encounter various theoretical, methodological, practical, and research difficulties.

A significant change in teacher education was the transition to a five-year Lower Primary School Teacher Training Master's study programme, which occurred in recent decades and was the subject of a demanding discussion with the representatives of educational policy in the Czech Republic - see the hearing in the Senate in 2002. It focuses on the preference for teachers' professional development being for five years. In this paper, we will deal with the chance of teachers' professional learning from only one perspective, in order to prove the results of the changes based on previous discussions about educational policy. We will observe the student portfolio as a quality tool for the evaluation and self-evaluation of pre-service lower primary teachers during and at the end of their studies. We will analyse the theoretical foundation for choosing portfolios as a tool for observation of professional learning from the point of view of educational science in preparation for the teaching profession in primary education. Reflection on student portfolios may be evidence capturing the individual strategies of students acquiring educational theories from primary education and evaluation of reflection on the results of teaching practice. Teaching practice, together with educational theory, runs through the five-year study programme of Teacher Training for Lower Primary Schools in a new teacher training model in Zlin, at the Faculty of Humanities at Tomas Bata University. This year, the first results of reflection on a recently chosen teacher preparation path are available. Additionally, new and interesting incentives for educational politics in relation to future teacher training in the Czech Republic emerge.

Keywords: teachers' professional learning, teacher training, reflective model, research on teacher education, assessment of professional learning, recommendation for educational policy 